\title{
DICTERIO, CONCEPTISMO Y FRASE HECHA: A VUELTAS CON EL VEJAMEN*
}

\section{A vUELTAS CON EL VEJAMEN}

En el Certamen poético celebrado en 1636 en la ciudad de Mallorca, en honor de Sor Catarina Tomasa, canóniga reglar de San Agustín, puede leerse al final del mismo: "Gallos o Vejamen en la Justa Poética..." 1. Veintisiete años después, en otro lugar y en otro certamen, Fernando de la Torre Farfán afirmaba: "no dilatemos su vejamen, que a buen seguro que no le extrañe los atrevimientos, supuesto que los ha visto tan cantados en Salamanca, adonde los diferencia sólo el nombre de gallos"2.

A pesar de estas palabras, y como ya sostuve en otro lugar ${ }^{3}$, en su origen el gallo era el vejamen exclusivo del teólogo. En esencia

* Este trabajo ha sido realizado gracias a una beca del M. E. C. (F. P. U.).

${ }^{1}$ Miguel Tomás, Certamen poético, en honor de la venerable madre sor Catarina Tomasa, mallorquina..., Gabriel Nogues, Barcelona, 1636. (He manejado el ejemplar de la Houghton Library, Harvard University, Span 4368.50*.)

${ }^{2}$ Fernando de la Torre Farfán, Templo panegírico, al certamen poético que celebró la hermandad insigne del Smo. Sacramento..., Juan Gómez de Blas, Sevilla, 1663, f. $215 \mathrm{v}$.

${ }^{3}$ F. Layna Ranz, "Ceremonias burlescas estudiantiles (siglos XVI y XVII): 1. Gallos”, Criticón, 1991, núm. 52, 141-162. Véanse, para más información sobre vejámenes, J. M. BlecuA, "El vejamen segundo de Anastasio Pantaleón de Ribera”, en The two Hesperias. Literary studies in honor of Joseph G. Fucilla on the ocasion of his 80th birthday, José Porrúa, Madrid, 1977, pp. 55-67; K. Brown, "Aproximación a una teoría del vejamen”, en De las Academias a la Enciclopedia, Edicions Alfons el Magnànim, Valencia, 1993, pp. 227-262; "Context i text del Vexamen d'acadèmia de Francesc Fontanella”, Llengua i Literatura, 2 (1987), 173-252; M. S. CARraSCO URGOITI, "Notas sobre el vejamen de academia en la segunda mitad del siglo xvII", RHM, 31 (1965), 97-111; "La oralidad en el vejamen de Academia", Edad de Oro, 7 (1988), 49-57; A. EgIDo, "De ludo vitando. Gallos áulicos en la Universidad de Salamanca", Crotalón, 1 (1984), 609-648; "Floresta de vejámenes universitarios granadinos (siglos XVII-XVIII)”, BHi, 92 (1990), 309-332; “Literatura efímera: ora- 
tanto uno como otro se reducen a lo mismo: dar vaya, matraca o cordelejo al aspirante al grado de doctor. Andando el tiempo, en certámenes, o en academias, o en fiestas, se igualaron ambos nombres. Pero en su origen, insisto, la palabra "gallo" indicaba que el vejado era un doctorando en teología.

Fernando de la Torre Farfán, conocido animador de las justas poéticas del siglo XVII, en el mismo certamen citado se hacía eco de la popularidad de los vejámenes: "En concluyendo, Urania, dijo Apolo que ya no serían menester más preámbulos para disculpar el atrevimiento disoluto de los vejámenes, pues constaba que, como ceremonia inexcusable, presentaba la antigüedad de su costumbre dondequiera" 4 .

En el vejamen que el doctor Salcedo dio al doctor Salazar en 1598 en la Universidad de Granada se puede ver cómo antes del ensalzamiento del aspirante, el vejamista ${ }^{5}$ hace referencia al carácter virulento y tradicional de estos actos: "Todo lo dicho hasta aquí, señores, ha sido violento, para cumplir con el antiguo y pesado estatuto de nuestra Universidad y así, como cosa violenta, no puede ser durable" 6 .

lidad y escritura en los certámenes y academias de los siglos de oro", Edad de Oro, 7 (1988), $69-87$ (luego recogido en Fronteras de la poesía en el Barroco, Crítica, Barcelona, 1990, pp. 138-163); "Un vejamen de 1598 en la Universidad de Granada”, en Silva de Andalucía (estudios sobre poesía barroca), Servicio de Publicaciones, Diputación Provincial, Málaga, 1990, pp. 175-204; A. GARCía BoIZA, "Un vejamen universitario. Que contiene unos gallos que se dieron en presencia de los Reyes", Basílica Teresiana (1921), 344-350 y (1922-23), 39-45; O. Gorsse, "Edición del Vejamen que en esta Academia del Buen Retiro dio Alfonso Batres secretario", en Edición y anotación de textos del Siglo de Oro. Actas del Seminario Internacional para la edición y anotación de textos del Siglo de Oro, eds. J. Cañedo e I. Arellano, EUNSA, Pamplona, 1987, pp. 111-129; J. E. LaPlana GiL, "Un vejamen en un tratado de predicación: el Triunfo de la Verdad (Madrid, 1649) de Ambrosio de Bondía”, AFA, 44/45 (1990), 179-208; F. LaYNa RANZ, "La tradición de las burlas estudiantiles en la Universidad de fray Luis de León”, en Actas del Congreso Internacional fray Luis de León (en prensa); I. RavasinI, "Una 'metapoetica' in un vejamen di Francisco de la Torre y Sevil", StI (1991/93), 97-116; recientemente M. M. García-Bermejo ha presentado una comunicación en el Congreso de la Asociación Internacional Siglo de Oro que lleva por título "La parodia en la génesis de los gallos universitarios".

${ }^{4}$ F. de la Torre Farfán, Templo Panegírico..., f. 114r. Véase R. Reyes Cano, "Fernando de la Torre Farfán, un animador de justas poéticas en la Sevilla del xviı", Dicenda (Arcadia. Estudios y textos dedicados a Francisco López Estrada), 6 (1987), 501-507.

5 Término documentado en la época, véase F. LAYNA, “Ceremonias burlescas...”, p. 160 .

${ }^{6}$ Editado por Aurora Egido en "Un vejamen de 1598 en la Universidad de Granada”, en Silva de Andalucía..., pp. 175-204, esp. p. 204. 
En el manuscrito 939 de la Biblioteca Nacional de Madrid se lee lo que el teólogo Diego Fraylla, antiguo rector de la Universidad de Zaragoza, relata de la visita que a la ciudad hicieron el rey Felipe III y la reina Margarita el 11 de septiembre de 15997. Entre sus ocupaciones oficiales estaba la de acudir al paseo y concesión de un grado de doctor en leyes. El paseo quedó fijado para el día 18 y la borla para el $19^{8}$. Diego Fraylla describe todo el ceremonial, y hace ver que una vez que el aspirante había terminado sus conclusiones:

se sentó en un banquillo donde estuvo cubierto con un capirote mientras duró el vejamen, el cual mandó su majestad se diese y lo dio el doctor Avenia, doctor en la facultad de leyes, estando sentado y cubierto con muy buen término y sin decir de otro alguno sino del graduando, y con brevedad dijo por qué en las Universidades se habían introducido los vejámenes, que era por humillar al graduando por que con el grado no se ensoberbeciese, y de ahí discurrió diciendo cinco o seis cosas muy bien dichas, graciosas, que causaron regocijo al auditorio ${ }^{9}$.

Por otro lado, Aurora Egido destacó la importancia de un párrafo de uno de los vejámenes (de 1742) incluidos en un volumen existente en la Biblioteca Nacional de Madrid y en el que se recogen varios de los siglos XVII y XVIII:

Es el fin de los vejámenes, según el señor San Gregorio, humillar al graduando, para que poniéndole sus faltas a la cara, no se ensoberbezca con la dignidad a que aspira. Así se practica hoy en las más de las Universidades de España; y esto que parece cosa de mofa, está autorizadísimo en las universidades más antiguas y en las primitivas academias, que podrá ver el curioso en Beyerlinch, en su Teatro: Verbis, Academia, Doctor, Doctrina. Para que se entienda cuán fundada está, y autorizada, esta ceremonia, que juzgará alguno ser cosa de risa ${ }^{10}$.

${ }^{7}$ Lucidario de la Universidad y Estudio general de la ciudad de Zaragoza y de las cosas y sucesos de ella, hecho por Diego Fraylla, presbitero doctor en sancta teología y Rector que ha sido de dicha Universidad... en el cual se declara todo lo sucedido y hecho desde su principio de la Universidad hasta el presente día de hoy que somos a 12 de marzo de 1603 [s. a., s. 1.].

8 Ibid., f. $97 \mathrm{v}$.

9 Ibid., f. $100 \mathrm{r}$.

10 Se trata del séptimo volumen de la Biblioteca Nacional de Madrid (BNM, R/10995), Laudatoria y Vejamen que en la Universidad de Granada se dio al Sr. D. Sebastián de Espinosa... del año de mil setecientos cuarenta y dos, [s. a., s. 1.]; cita en preliminares, sin numeración, pero corresponde a la signatura IIIII2. A EGIDo, "Floresta de vejámenes...", p. 311. 
Y añade la profesora Egido la cita de la enciclopedia de Laurens Beyerlink (1578-1627) en la que se especifica "la existencia del vejamen en diversas universidades y academias, justificando el uso para que no se ensoberbezca el doctorando con su sabiduría adquirida" 11 . Nótese que es la misma soberbia y envanecimiento que muchísimos años antes había denunciado Petrarca a propósito de una ceremonia de doctoramiento ${ }^{12}$. Pero volvamos a ese vejamen de 1742 para poner mientes en algo verdaderamente curioso: una reflexión inicial por parte del censor del mismo, un tal Francisco Barbán de Castro, sobre la secular concomitancia de lo jocoso y lo serio:

Yo no sé qué tiene lo jocoso que aun entre lo más serio y circunspecto se halla bien visto. No lo juzgaron improprio de la grave compostura de sus togas los senadores romanos... Y en las bodas más graves no parecía que había boda si no se componían aquellos versos Fesceninos, que a no haber sido obscenos, en nada desmerecieran los aplausos que se granjeaban por jocosos y agudos. Los dichos buenos y chistosos es fuerza que sean buenos, porque tienen gracia, y en ella caen a todo hombre de buen gusto. Pero no sólo a los hombres, que hasta los dioses gustan de lo jocoso, según dice un proverbio... De el dosel y el estrado, pasemos a los templos, y hallaremos que desde que Jambe (graciosa viejecilla) hizo a Ceres que soltase la risa... siempre ofrecían los sacrificios a esta diosa, mezclando agudos motes y risueños chistes con las más serias ceremonias de sus cultos, al modo que con los más sagrados y respetuosos se mezclaron después en nuestros templos los que hoy llamamos villancicos y nuestros antiguos chanzonetas. Con que vuelvo a decir que no sé qué se tiene lo jocoso que con todos hace migas... y ni aun con lo serio y santo está reñido.

Siendo esto así, no estraño que con los doctos y sabios haga también liga..., den a la jocosidad los buenos días, admitiéndola entre sus actos literarios por paréntesis de sus más serias tareas ${ }^{13}$.

${ }^{11}$ Id., esp. n. 3. La ed. que maneja la profesora Egido es Laurentio BeyerLinck, Magnum Theatrum Vitae Humanae... Tomus secundus, Sumtibus Joannis Antonii Hugetan, Lugduni, 1689, pp. 1035-1036.

12 Petrarca, Remedios contra próspera y adversa fortuna, trad. de Francisco de Madrid, Valladolid, 1510, libro 1, diálogo 12, signatura C4.

${ }^{13}$ Laudatoria y Vejamen..., IIIII ${ }^{2}$ ss. Son casi literalmente las mismas palabras dirigidas al lector en el vejamen celebrado en Granada en 1687: "Ceres, largamente fatigada en busca de Proserpina, a quien ocultaban profundamente los abismos, mientras en las soledades Eleusis, sobre un peñasco llamado el Irrisible, se estaba consumiendo de tristeza, pensando siempre en su Proserpina, Jambe, viejecilla graciosa, con festivos motes la hizo reír. De donde tuvo origen que en los arcanos sacrificios de Ceres con lo serio de las ceremonias venerandas se mez- 
Parece desprenderse de estas palabras que la burla no fuera una excepción, sino el elemento de una "mezcla", como si las burlas y las veras conformaran las dos caras de una misma moneda. La referencia al mito de Ceres y Proserpina da pie a que lo jocoso se traduzca como una regular y necesaria presencia en el mismo contexto de su paralelo serio ${ }^{14}$. Se intuye que de ahí a esa especie de exigencia del vejamen hay muy poca distancia. Tras esta reflexión de un hombre del siglo XVIII sobre la sempiterna aparición de la burla, vayamos a las anteriores alusiones al porqué del vejamen, a su "atrevimiento disoluto", a la necesidad de humillar al graduando para reducirle la soberbia. Además de comprobar que por lo visto Felipe III era bastante aficionado a asistir a este tipo de ceremonial ${ }^{15}$, y que su presencia no supone la eliminación del vejamen -acaso sí una reducción de su virulencia, como parece deducirse de las palabras de Diego Fraylla ("cinco o seis cosas muy bien dichas, graciosas")—, además de esto, este hablar del vejamen parece funcionar como lugar común, como exordio estipulado por el uso. Ahora bien, si se trata de un requisito secular, si su costumbre fuera tal que a nadie asombrase su práctica, ¿a qué divagar acerca de su naturaleza o sobre su ineluctable presencia?

La agudeza y sus manifestaciones, el mote y el apodo, eran motivo de vanagloria nacional. Todo hombre discreto que alardease de cortesano había de ser experto en el arte de la agudeza. Y si en otras lenguas los juegos de palabras, los equívocos y sutilezas se consideraban defectos, en la española eran adornos. Los preceptistas, en cambio, dejaban clara la necesidad de cautela y moderación en los dichos. Luis de Zapata recomendaba que los dichos y motes no fueran sucios ni deshonestos, ni desacatados a Dios ni al Rey, ni que dieran lástima ni malicia, ni que fueran contra la honra16.

clase lo ridículo de entretenidos motes. Y donde nació el proverbio: hasta los Dioses gustan de lo jocoso", volumen de varios vejámenes cit. supra, n. 10, p. 4 (cada vejamen tiene numeración independiente).

14 Yambe hizo reír con sus bromas obscenas a Ceres (o Deméter), de ahí que se dijera que en los misterios de Eleusis hubiera una parte, como conmemoración de la anécdota, donde se utilizaba este tipo de burla obscena.

15 También están presentes Felipe III y la reina Margarita en el gallo incluido por Gaspar Lucas Hidalgo en sus Diálogos de apacible entretenimiento, cf. F. LaYNA, "Ceremonias burlescas...", pp. 157-161.

${ }^{16}$ Luis Zapata de Chaves, Miscelánea, sel. de A. R. Rodríguez Moñino, Cía. Iberoamericana de Publicaciones, Madrid-Barcelona-Buenos Aires [s. a.]. Igualmente en las Constituciones y Estatutos de régimen interno universitario se recoge, ya desde el siglo xvi la prohibición de burlas e insultos, véase nuevamente F. Layna, "Ceremonias burlescas...”, p. 153. 
Pues bien, el vejamen es el género más rafez y malicioso de que dispuso la burla, y yo casi diría que en la segunda mitad del siglo XVII tenía como condición fundamental atentar contra la honra de los vejados. Debió de generar muchísima mala sangre. Se puede pensar que es una sorna de espacio cerrado, y por tanto con mayor capacidad para alterar los supuestos buenos principios, pero ya es sabido que a los vejámenes acudía la flor y la nata de la sociedad universitaria, y personajes principales, y los mismos monarcas. Esta aparente obligación explica las numerosas alusiones a la existencia del vejamen, como queriendo decir: lo impone la costumbre, a todos nos resulta censurable esta vejación, pero así es, herencia legendaria, aunque falsa, como veremos más adelante. Zaherir es la condición, que nadie dude de la capacidad de maledicencia del vejamista:

¡Válgame Dios! ¿Es posible que siendo yo desde mi primera camisa y papas de un natural dócil, modesto, blando y pegajoso, en tan breve tiempo, por sólo lo que me retintina la voz indigesta y cejijunta de mi fiscal nombre, haya dado en que me tengo de endiablar contra mis mayores amigos?... ¿Y esto no más por no dejar el puesto a los sucesores con el mal ejemplo de haber almibarado lo que debe ser (y será con el favor de Dios) mordacidad pura, clara, lisa, lega, llana y abonada...? ${ }^{17}$.

Con el tiempo el vejamen pierde su pertinencia universitaria. Buena prueba de ello es la gran cantidad de pequeñas composiciones que reciben esa denominación, dirigidos a un sinfín de personajes, a un sacristán ${ }^{18}$, a Judas ${ }^{19}$, al diablo ${ }^{20}$, o vejámenes escritos para certámenes poéticos o fiestas de canonización. Es sabido que Santa Teresa de Jesús escribió y sufrió vejámenes, y que Alonso de Ledesma los elevó a lo divino ${ }^{21}$. Así pues, el término vejamen

17 Academia que se celebró en Badajoz..., Julián de Paredes, Madrid, 1684, p. 29.

18 Véase Simón Díaz, Bibliografía..., 4, núm. 1293 (12).

19 Véase Antonio Rodríguez Moñino, y María Brey Mariño, Catálogo de los manuscritos poéticos existentes en la biblioteca de The Hispanic Society of America, The Hispanic Society of America, New York, 1965, t. 1, p. 442.

${ }^{20}$ José Medina (ed.), Vejamen del Diablo por el chasco que se llevó en la Concepción de la Virgen María, Méjico, 1634; véase n. 223; o "Vejamen que da al diablo", en Museo en que se describen diferentes poemas que compuso el Doctor Don Duarte Nuñes de Acosta..., ms. BNM 3891, pp. 48-51.

21 "Al ilustrísimo señor don Álvaro de Mendoza, obispo de Ávila. Es la que llaman del vejamen”, en Cartas de Santa Teresa de Jesús, Imprenta de Mercurio, Madrid, 1752, pp. 28-36 (carta 5); "Vejamen que hizo un religioso cartujo a la Santa Teresa de Jesús", en Retrato de la fiestas que a la beatificación de la bienaven- 
se divulga como sinónimo de reprensión y sátira general, por lo habitual en verso. Góngora, por el contrario, no se queda sólo en la anécdota o en la alusión cuando escribe su Vejamen que se dio en Granada a un sobrino del administrador del Hospital Real...22, sino que intenta una composición con qué vilipendiar a un graduado utilizando los mismos recursos practicados en los vejámenes universitarios y de academia, es decir, apodos, equívocos, etc. Se dirige al auditorio, utiliza los archiconocidos juegos del "orate/frates" y de Santo Tomás y Escoto, alude a la bizquera del graduando, a su vanidad, al apadrinamiento de su tío; comenta equívocamente que

Hanos traído, pues, hoy este nieto de Pos Podos (por lo cumplido de pies según la regla de Antonio)

y finaliza con matracas al uso, por ejemplo

Seáis por lo autorizado

mucho más grave que el plomo

para concluir anunciando que

trompas de la fama digan

que se gradúan ya trompos.

Puede verse la generalización del vejamen en el que Quevedo escribe a una dama o en aquel otro en que el ratón lo hace del ca$\mathrm{racol}^{23}$. Al final de éste, Quevedo nos aclara algo que en verdad interesa para comprender mejor la naturaleza del vejamen:

turada virgen y madre Santa Teresa de Iesús... hizo... la imperial ciudad de Zaragoza..., Luis Díez de Aux, Zaragoza, 1615, pp. 13-15. Alonso de Ledesma, "A San Pablo, en vejamen. Vejador, Fe, Caridad, Religión y Constancia (las cuatro damas que están a las ventanas oyendo dar el vejamen)", Conceptos espirituales, en Romancero y cancionero sagrados, $B A E$, t. 35, 1872, pp. 234-236. Véase también J. E. LAPLANA GiL, "Un vejamen en un tratado de predicación: el Triunfo de la Verdad (Madrid, 1649)", Archivo de Filología Aragonesa, 44/45 (1990), 179-208.

22 Luis de Góngora y Argote, Obras completas, ed. de J. Millé y Giménez e I. Millé y Giménez, Aguilar, Madrid, 1956, pp. 179-183.

23 "Vejamen a una dama. Romance burlesco" (núm. 778), en Obra poética, ed. de J. M. Blecua, Planeta, Madrid, 1971, t. 3, pp. 124-128; y, en este mismo tomo, "Vejamen que da el ratón al caracol" (núm. 758), pp. 35-37. 
Pero de matraca baste, que yo espero gran respuesta; y aunque soy más cortesano, me he de correr más apriesa ${ }^{24}$.

Con el anuncio de que se abandonan las burlas suele el vejamista iniciar la laudatoria del nuevo doctor. Quevedo cesa en su matraca, pero no para loar a nadie, sino a modo de reto, de espera de la respuesta. Esto nos induce a pensar que con este vejamen al caracol en realidad se está dirigiendo a alguien en concreto. Y los dos últimos versos, que estimo de gran importancia: aunque lo cortesano estipule que ha de recibirse el vejamen sin contestación, sin manifestar agravio o corrimiento, Quevedo se reconoce ansioso por conocerla, y avisa de algo que en principio censuraban las buenas costumbres. De esta manera altera las reglas del juego, de igual forma que en otros lugares trasteja la fosilización de chistes, apodos y equívocos canonizados por el tiempo. El vejamen exigía una sola dirección en su desarrollo, imponía la imposibilidad de rechazo o respuesta, algo que Quevedo no parecía muy dispuesto a aceptar. De la ligera reprimenda, aconsejada en los cortesanos, urbana, ágil, de hombre de bien, se llega a una actividad vejatoria sin vallas en su capacidad de escarnio. Y aun más, esta ausencia de tope recibe el espaldarazo del poder más absoluto: la presencia de los reyes, que confirma el carácter consagrado y hasta "oficialista" del vejamen como arquetipo de comicidad para la sociedad de la época ${ }^{25}$. De ahí que se nombre la historia, la primitiva bruma de donde deriva lo insoslayable de la invectiva, tal que una verdad indestructible e incuestionable. La gente asistía a las ceremonias de grado y a las justas nada más que para oír los vejámenes ${ }^{26}$, síntoma inequívoco de la agresividad y corrosiva beligerancia de una sociedad. No tiene sentido que un género litera-

24 Ibid., p. 37.

${ }^{25}$ Los reyes no hacían sólo acto de presencia, sino que a veces incluso decidían quiénes habían de ser los vejamistas. Por ejemplo, fue voluntad de los monarcas que Rojas Zorrilla diera el vejamen en el certamen de 1638 celebrado en el Buen Retiro, vejamen que en un principio se había designado a Alfonso de Batres y a Antonio Coello, véase E. Cotarelo y Mori, Don Francisco de Rojas Zorrilla, Imprenta de la Revista de Archivos, Madrid, 1911, pp. 58-60.

${ }^{26}$ Es muy significativo que en las cartas de jesuitas sólo se mencione el vejamen como lo más destacable de todo el certamen: "Después ha habido todos los días algún género de entretenimiento en el Retiro, y el certamen poético, y el vejamen, que fue muy celebrado, y hoy tienen mojiganga de todos los señores..." (Memorial Histórico Español..., Imprenta Nacional, Madrid, 1862, t. 14, p. 335). 
rio que goza del favor del público apele por sistema a la tradición, a la antigüedad de su uso; antes bien refleja todo lo contrario, además de ser una convención para, aparentemente, atenuar la carga del denuesto. En otra ocasión ya reflexioné acerca de cómo un maestro "galleante" se preguntaba por la razón del ineludible "gallo" que habían de sufrir los teólogos ("Ceremonias burlescas...", pp. 154-55). Su conjetura lo lleva a un respaldo de consideración: la Biblia, la palabra de Dios. Ahora bien, esto es un asunto de muy distinta naturaleza, me refiero al motivo que explique que en cenáculos religiosos se destinara una parte de la realidad a la burla. Aunque aquí la Biblia puede funcionar exactamente igual que la cita de la tradición en los vejámenes más tardíos, es decir, autoridad y acatamiento. De cualquier forma, hay un gran distancia que va de la licencia que los teólogos se permitían para condimentar el acto de doctoramiento, "con la sal de alguna tentadora alegría, con algunas facecias y dichos mordaces" (id.), a la institucionalización del vejamen más corrosivo y malintencionado, donde no hay lugar a la "tentación", y sí vía libre para que se sublime la exigencia de un modo de vida en que la agresión desde situaciones de privilegio, la murmuración y el derramamiento de sangre moral adquieren la categoría de fundamentales y aceptados.

\section{LA INVOLUNTARIEDAD DE LO DICHO: ESTRUCTURA DEL VEJAMEN}

Está claro que mediante la ensoñación se desvía la responsabilidad de lo dicho ${ }^{27}$. Sin duda un buen artificio para el vejamen, quizá por influencia lucianesca, y el más frecuente, aunque no exclusivo.

Costumbre ha sido siempre... dormirse en semejantes trabajos ${ }^{28}$.

Ello está de Dios que nos hemos de andar durmiendo los ministros de las Academias ${ }^{29}$.

${ }^{27}$ Para el estudio del sueño como género habitual en la época, véanse, entre muchos, El sueño y su representación en el Barroco español, ed. de D. Cvitanovic, Instituto de Humanidades, Bahía Blanca, 1969 y Miguel Avilés, Sueños ficticios y lucha ideológica en el Siglo de Oro, Editora Nacional, Madrid, 1980.

28 José Navarro, Poesías varias, Imprenta de Miguel de Luna, Zaragoza, 1654 , p. 53.

29 Antonio Coello, "Vejamen que se dio en el Certamen del Buen Retiro, año de 1638”, en Antonio PaZ y Melia, Sales españolas, BAE, t. 176, 1964, p. 317. 
Cuentan los maldicientes que la murmuración es hija del sueño y de la noche... Y dicho y hecho... quedéme como un pajarito ${ }^{30}$.

Pantaleón de Ribera sueña que asciende a la luna para su vejamen de la Academia de Madrid ${ }^{31}$. Cáncer duerme y sueña que los poetas latinos e italianos tienen sitiado el Parnaso, que el padre Apolo solicita ayuda a los poetas castellanos, y que en esa contienda combaten Luis de Belmonte, Alfonso de Batres, Francisco de Rojas, Juan de Zavaleta, Vélez de Guevara, Matos Fragoso, Moreto... ${ }^{32}$.

Por otra parte, hay casos, muchos, en que se reniega a plena conciencia de esta convención:

Yo, pues, he pretendido desvelado no dormirme ni aun en las pajas, que a ingenios tan peregrinos no quisiera ofenderlos, ni aun por sueños ${ }^{33}$.

\section{Cuando con apodos mil \\ Nos desazona un fiscal, \\ Es su oficio criminal \\ Pero su modo civil.}

Vele, pues, y en sus enojos

No se mostrará inoportuno,

Ni por sacarnos el uno

Se quiera quitar dos ojos ${ }^{34}$.

30 Academia que se celebró por Carnestolendas, jueves 21 de febrero de este año de $1675 . . .$, Oficina de Lucas Antonio de Bedmar, Madrid, p. 85.

31 Anastasio Pantaleón de Ribera, Obras, ed. de R. de Balbín Lucas, C.S.I.C., Madrid, 1944, t. 2, pp. 11-13.

32 Ateneo, 7 (1909), 156-163. Son frecuentísimos estos juicios celebrados en la corte parnasiana. En ellos, Apolo pretende salvaguardar la poesía castellana de la turba de poetastros que la amenazan. A tal punto se llega que en el "Juicio final de todos los poetas españoles muertos y vivos" (incluido en alguna versión de la Academia burlesca de 1638) se cuenta que, favorecido por este ambiente de asedio a la "buena y vieja poesía", apareció "por las calles y plaças de Madrid un hombre prodigioso bestido de carteles de comedias, de justas literarias, y Rrenjifos, que llamaron Antipoeta (Ante-Christo) que predicaua doctrinas nueuas de poesía, y metía a los muchachos seguidillas entre las vñas...", H. E. Bergman, "El Juicio final de todos los poetas españoles muertos y vivos (ms. inédito) y el Certamen poético de 1638”, BRAE, 55 (1975), 551-610, cita en p. 571.

33 J. Navarro, Poesías varias, p. 53.

34 Ibid., p. 141. Véase Academia que se celebró en día de Pascua de Reyes..., Madrid, 1674, p. 43; "Vejamen que dio D. Juan de Orozco en casa del contador Agustín de Galarza”, en A. PaZ y Melia, Sales españolas, p. 325. 
En la Academia de Badajoz de 1684, un diablo increpa y espeta al vejamista Francisco Félix de Vega y Cruzar:

Vengo contra vos porque sin autoridad bastante habéis desterrado del vuestro vejamen los sueños, y porque tememos que con igual osadía descartaréis también los diablos, segunda principalísima parte desta acción en la vulgar pedantería fiscalizante ${ }^{35}$.

Porque, efectivamente, el diablo fue habitual compañero del vejamista, quien le inducía, quien le acompañaba o quien le entregaba el vejamen. En esta misma Academia, Francisco Félix de Vega contempla el prodigio de cómo la tierra se abre y de sus profundas simas asoma un diablo, sahumado de pebetes infernales, y ante tal visión exclama: "Ya está el diablo en campaña, desfrutémosle" 36 . El recurrente, socorrido diablo. Ejemplos hay para dar y tomar. Ahora bien, no siempre tiene por qué tratarse de un demonio. Sirve al caso un romero ${ }^{37}$, un loco $^{38}$, un desconocido estudiante, el viejo maestro en disparates Juan del Encina... Muchos, en definitiva, son los llamados a aliviar la carga al maestro graduado o fiscal de academia encargados del tan comprometido vejamen. En el dado en la Universidad de Granada en 1679, Juan del Encina se ofrece para ayudar con una sarta de equívocos y disparates ${ }^{39}$; en el de la Universidad de Granada de 1687, la mula desvía al doctor contra su voluntad y le dirige al Hospital Real, puesto que el mismo animal estima gran locura haber aceptado el envite del vejamen. Allí, en el hospital de locos, un desconocido estudiante, llamado Juan, seguramente también Juan del Encina, le ofrece ayuda, y le escribe un entremés de boberías injerto en mojiganga ${ }^{40}$. En las fiestas celebradas en Valencia en honor de San Juan de Mata y San Félix de Valois, el vejamista, fray José Carbó, conoce a un moro poseedor de un portentoso espejo, mediante el cual ambos contemplan a los personajes del vejamen ${ }^{41}$. En la justa poética celebrada en Orihuela el año de 1635, "un hombrecillo cariestevado y bizco de persona", poeta y astrólogo, le deja al fis-

35 Academia que se celebró en Badajoz, p. 31.

36 Ibid., p. 30.

${ }^{37}$ J. Navarro, op. cit., pp. 142 ss.

38 Ibid., pp. 55 ss.

${ }^{39}$ Volumen de varios vejámenes (cit. supra, n. 10), pp. 2 ss.

40 Ibid., pp. 6 ss.

${ }^{41}$ Sacro y solemne novenario..., Imprenta de Benito Macé, Valencia, 1669, pp. 507 ss. 
cal "un pronóstico y poetario general desta justa de 1634", es decir, el vejamen propiamente dicho ${ }^{42}$. Frente a este compromiso de la injuria ${ }^{43}$ había que buscarse las mañas, y qué mejor que volver a la ensoñación, a la visión onírica y a la aparición de un personaje que aparentemente cargase con las culpas de lo proferido. José Navarro, vejamista de la Academia del Conde de Lemos, se encuentra con un romero que censura la práctica habitual de los vejámenes de soñar con el monte, con la fuente o con el caballo de las musas. El peregrino le indica que le vendrá bien encontrarse con un vejamen ya hecho

...con que poder decir lo que quisieres, y después con echarle la culpa a este pobre peregrino... [saca un espejo] Y como maestro de títeres que va declarando los personajes de un retablo, dijo:

-Aquí verás todos los académicos de la manera que agora se hallan en sus ejercicios ${ }^{44}$.

Son éstos viejos recursos utilizados habitualmente por la literatura de tinte satírico. En vejámenes, los artificios alegóricos o ensoñaciones visionarias sirven aparentemente para mitigar la responsabilidad directa del vejamista. Pero sólo en apariencia. De ello es muy consciente Antonio Coello cuando finaliza su vejamen para la Academia del Buen Retiro: "Si alguno se hubiera enojado, sueñe que me descalabra, pues yo soñé que burlaba con él, y yo le daré firmado de treinta capitanes que cumple con esto, y que la venganza ha de ser de la manera que fue el agravio" 45 .

Es muy citado que, tras esta academia, uno de los encargados de dar vejámenes, en concreto Francisco de Rojas, recibió una cuchillada que en la época se relacionó con alguien que no asimiló muy bien las burlas de las que fuera víctima ${ }^{46}$. Y es que, en este sen-

42 Pedro de Castro y Anaya, Justa poética y festividad votiva..., Juan Vicente Franco, Orihuela, 1635, en A. PÉrez Gómez, y M. Cortés MuÑoz, Justas y certámenes poéticos en Murcia (1600-1635), Biblioteca de Autores Murcianos, Murcia, 1958, t. 2, pp. 376-388. Éste es el único caso que conozco de vejamen con título: "El salpullido, el sabañón de los poetas, el bufón del buen hábito, el lacayo de la Justa. El vejamen".

${ }^{43}$ Así definido por el vejamista Francisco de Avellaneda, Fénix de los ingenios... Certamen que se dedicó a N. S. de la Soledad, Diego Díaz de la Carrera, Madrid, 1664, f. 142r.

${ }^{44}$ J. NAVARRO, op. cit., p. 145.

45 A. PaZ y Melia, op. cit., p. 321.

${ }^{46}$ La información parte fundamentalmente de E. Cotarelo y Mori, op. cit., p. 61. Véanse también M. Soledad Carrasco Urgoiti, art. cit., pp. 97-111; H. E. BERGMAN, art. cit., pp. 567-8; K. BROWN, art. cit., p. 232. 
tido, si se avanza en el tiempo se comprueba una mayor conciencia del riesgo corrido, miedo incluso a las posibles consecuencias derivadas del improperio público: "y así, empiezo con mucho temor, porque todos son contadores y letrados, y si se enojan, unos dirán leyes y otros darán cuenta de mí" 47 .

De ahí que para curarse en salud, y dada la insoslayable obligación de su débito, sea común que el vejamista inicie o finalice su tarea consigo mismo, maldiciendo su suerte, considerándose mal poeta, de pocas luces y poca gracia, o bien descubriendo en público sus defectos físicos:

Aquí fuera bien que sin pasar más adelante me vejara yo a mí propio, porque no hay razón para que haga poner colorados a otros, y no me quede tan amusco como soy, y más pudiendo vejarme mejor que nunca después que estoy en servicio del Duque mi señor, porque en la sala de los espejos me he visto de pies a cabeza donde he podido descubrir mis defectos ${ }^{48}$.

Todos estos ejemplos de la "inexcusable obligación del oficio" 49 que lleva a decir, a oír o a ver lo que no se quisiera, pertenecen a la más rancia tradición de la sátira. "Difficile est saturam non scribere", argüía Juvenal. La estructura del vejamen no es muy innovadora que se diga; el insulto, tampoco. Otra cosa, y muy distinta, es el motivo de su aparición como paralelo burlesco de una ceremonia seria, al igual que su institucionalización como género de la sorna de una época. "¿Quién creyera que haya llegado tiempo de haberse hecho la más estéril materia tan dilatada para todos, como es la de maldecir?", se preguntaba el vejamista de la Academia universitaria de $1672^{50}$. E instado al cumplimiento de la obediencia, le llegó el sueño, "asilo de estos empeños". Pero aquella interrogación no es sino un puro eufemismo convencional. A estas alturas ya es muy añosa la relación entre maledicencia y deseo de que ésta sea atribuida a causas ajenas al que malquista.

47 Vejamen de Juan de Orozco, en A. Paz y Melia, op. cit., p. 325.

48 Academia jocosa conque se celebraron el nacimiento del excelentísimo señor Conde de Aliaga y..., en José SÁnchez, Academias literarias del Siglo de Oro, Gredos, Madrid, 1961, p. 125.

49 Academia que se celebró en Badajoz, f. 29r.

50 Academia que se celebró en la Universidad de Salamanca en tres de Enero de 1672. En casa del señor Don Luis de Losada y Riudeneyra, su Rector..., Melchor Estébez, Salamanca. 
El vejamen, como ya se ha dicho varias veces, aparece primero en ámbitos universitarios y escolares para pronto convertirse en uno de los géneros burlescos más característicos del siglo Xvir. En las academias, tan en boga en la época, todo el mundo esperaba la aparición del fiscal, o lo que es lo mismo, la llegada del encargado de dar el temido vejamen. Es a partir de la segunda mitad del siglo cuando las llamadas "cédulas" se erigen en uno de sus elementos definitorios. Entonces se produce un proceso inverso: la influencia de la academia y la justa en los vejámenes universitarios es evidente en esta especie de oráculo humorístico. No obstante, es fácil encontrar cédulas antes de esta fecha. Muy aficionado a ellas era Lope de Vega, de las que echó mano en la justa poética celebrada por la beatificación de San Isidro en 1620, y más tarde en la Relación de las fiestas que celebró Madrid por su canonización en 1622. En esta última reflexionaba Lope acerca de las cédulas:

Es tan admitida y observada costumbre de las Academias de España el recibir y el leer las Cédulas que se dan a los que leen, o sea en oposiciones o en vejámenes, que no he podido excusarme de traer a la presencia de Vuestras Magestades las que me han dado en las puertas de su Real Palacio, suplicándoles que, pues honran este acto de poesía con su grandeza, dándoles el lugar que merecen entre las demás ciencias y facultades, no se tengan por deservidos de que las lea ${ }^{51}$.

Entrambasaguas, para el que las cédulas fueron innovación del Fénix, sostenía que en la apelación a la costumbre había que leer "costumbre de Lope en las Justas" 52. Pero no se trata de eso, sino de aquel falso recurrir a la tradición que veíamos en los vejámenes de los cuales las cédulas se diferencian en muy poco. Recuérdese, por otra parte, que en La pícara Justina la turba estudiantil de la Vigornia organiza una máscara de repente, con disfraces de tipos o figuras fácilmente identificables, incluida una variante del célebre obispillo, además de bailes y ademanes, y algo que nos interesa especialmente: la entrega de cédulas, motes, papeletas es-

${ }^{51}$ J. DE Entrambasaguas, "Las justas poéticas en honor de San Isidro y su relación con Lope de Vega”, Anales del Instituto de Estudios Madrileños, 4 (1969), 27-133, cita en p. 84.

$52 \mathrm{Id}$. 
critas que eran arrojadas desde el carro. Esto nos obliga a diferenciar dos tipos de cédulas:

a) aquellas que se arrojaban en las fiestas callejeras y en las que por lo general se escribían los motes, y

b) las reducidas al ámbito exclusivamente académico, más cercanas a lo que he llamado "oráculo burlesco", y que hubieron de influir en los festejos estudiantiles ${ }^{53}$.

Sin duda estos dos tipos tienen muchas afinidades, y quizá la más estrecha sea la de su brevedad, característica que recoge Covarrubias cuando anota que "Todo escrito breve se llama cédula". ¿Qué eran, pues, y en qué consistían las cédulas académicas? Pueden ser definidas como un subgénero dentro de la estructura de academias, justas literarias, certámenes festivos, etc., y junto al vejamen -o formando parte de él- constituye la parte jocosa del acto. El secretario de la academia, generalmente encargado de su apertura, era el autor de estas piezas de agudeza ${ }^{54}$ en las que finge ser portavoz e intermediario de las demandas más disparatadas o preguntas más absurdas que personajes eminentemente burlescos dirigen al tribunal de la Academia:

Estilo, señor, de las Academias españolas es leer el secretario algunos papeles extraordinarios que algunos sujetos consultan a la Academia como a Oráculo, y ello da satisfación ${ }^{55}$.

A ti a quien toca las cédulas, que son respuestas que da el Oráculo de la Academia a diferentes preguntas que se le hacen ${ }^{56}$.

Esto es lo que distingue a vejámenes y cédulas: la pregunta, demanda o ruego que se formula al tribunal, y la sentencia que en

${ }^{53}$ En ocasiones, también el vejamen, llegado un momento, se verá inmerso en el global de la fiesta barroca; véase M. J. Rodríguez Sánchez de León, "La academia literaria como fiesta barroca en tres ejemplos andaluces (1661, 1664 y 1672)", DHA, 8 (1989), 915-926.

54 "Antes de abrir del todo el torneo poético, he resuelto promulgar, no cedulillas, como suelen, sino cedulones" (Torneo poético en loor del Ilustrísimo y Reverendo Sr. D. Fray José de Linás... celebrado en dicha ciudad por los alumnos del Seminario de Humanas Letras que hay en el Colegio de la Compañia de Jesús, Pascual Bueno, Zaragoza, 1695, f. 12r); "Empecemos en gracia de Dios con unas que llaman cedulillas por mi desgracia" (Justa literaria y certamen poético en la canonización de San Juan de Dios, Imprenta de Bernardo de Villa-Diego, Madrid, 1692, p. 10).

55 Academia que celebraron los ingenios de Madrid el día 11 de Enero de 1682..., Madrid, 1682, p. 11.

56 Academia con que el Excelentísimo Señor Marqués de Jamaica celebró los felices años de su Magestad la Reina... María Ana de Austria el día 22 de diciembre de 1672, Juan Vejarano, Cádiz, 1673. 
la cédula se le otorga. No es infrecuente que los personajes vejados aparezcan igualmente en la demanda. A veces una redondilla o quintilla pone el broche, fijando en verso lo que se relató en prosa. También acaso se separen cédulas y vejámenes en que por lo habitual en aquéllas la invectiva se presenta más diluida, menos concreta y más ambigua. Lope, por ejemplo, en la Justa poética y más tarde en la fiesta de la canonización, compone unas cédulas de las que parecen desprenderse críticas a Juan Ruiz de Alarcón y a Góngora, en un intento, como dice Márquez Villanueva, de consagrar patrióticamente el conceptismo ${ }^{57}$. Ahora bien, aquí no se especifica persona, no se nombra, tan sólo se sugiere, aunque con toda la mala intención posible, que no en vano en la época sería reconocida y celebrada como tal ${ }^{58}$. Por lo demás, en nada se diferencian cédulas y vejámenes: equívocos, falso amparo en una falsa tradición, dicterio, e incluso la convención de la culpa eximida, dado que el que lee las cédulas dice haberlas recibido de otras manos. No hay aquí sueño como en el vejamen, pero en su lugar la demanda burlesca se hace ver como formulada por alguien no conocido. Lope se justificaba con un 'déjenme que les lea a sus magestades las cédulas que me han dado en la puerta de su palacio'.

En esta unión de cédulas y vejamen, y en el ámbito cerrado del certamen, se integra toda una gama de figuras que constituyen permanente objeto de burla en obras festivas de mayor calado y en las formas de teatro breve. Se trata de los consabidos poetas remendones de coplas, viejas calceteras, astrólogos perogrullescos, glosadores de repente, soldados apicarados, zapateros, médicos, cerrajeros, galanes burlados y una larga lista de elementos cómicos conocidos:

Un médico tan llano que a cualquiera parte que va se entra hasta la cama, tan docto en su profesión que al enfermo que no puede comer luego le envía a cenar con Cristo, tan mañoso que teniendo una figura asquerosa, las damas se mueren por él...59.

${ }^{57}$ F. MárQuez Villanueva, Lope: vida y valores, Editorial de la Universidad de Puerto Rico, 1987, pp. 109-140 para las justas isidriles; para cita, p. 113.

${ }^{58}$ Justa poética y alabanzas justas que hizo la insigne villa de Madrid al bienaventurado San Isidro en las fiestas de su beatificación, recopilada por Lope de Vega, viuda de Alonso Martín, Madrid, 1620 (cédulas en ff. 10r-12r); véase Entrambasaguas, "Las justas poéticas en honor de San Isidro...", pp. 42-44.

${ }_{59}$ Academia que se celebró en veintitrés de Abril de 1652 en casa de don Melchor de Fonseca y Almeyda..., Madrid, 1662, f. 3r (segunda Academia de las dos encuadernadas en el volumen de la BNM R/5193). 
Un soldado de puro roto, destos que en el cuerpo son Martes y en el vestido Dominguillos, buen embestidor y mal embestido... ${ }^{60}$.

Ya hemos hecho notar que la lectura de estas cédulas formaría parte de una ceremonia inicial o introductoria en la que, en ocasiones, también se incluían otros recursos poéticos y musicales que no viene al caso analizar ${ }^{61}$. Y que, a juzgar por algunas referencias y las propias acepciones que recogen los repertorios lexicográficos, vendría a constituir una mínima acción, consistente en sacar al azar, de las muchas previamente escritas, algunas de estas piezas para ser leídas ante los jueces y el auditorio en general ${ }^{62}$. Parece, de esta forma, existir cierta equivalencia entre las octavillas (también llamadas así) o cédulas que desde los carros triunfales de la máscara son lanzadas a los asistentes de la fiesta callejera ${ }^{63}$, y estas otras de fiesta interior más literaria. Aunque estas últimas pueden igualmente reproducir el paseo de una mojiganga festiva. Esto se comprueba en la Academia celebrada en Madrid durante el car-

${ }^{60}$ Academia que se celebró en siete de Enero en casa de D. Melchor de Fonseca Almeyda, siendo presidente D. José Porter y Casanate, secretario D. Luis de Oviedo y fiscal D. Juan de Montenegro y Neyra, Francisco Nieto, Madrid, 1663, f. 3r.

${ }^{61}$ Es frecuente que antes de comenzar la Academia se haga una invocación poética cantada que da paso a la intervención del secretario. Éste, antes de leer las cédulas, recurre a un preámbulo en el que a menudo se inserta la "Carta de Apolo" (véase, por ejemplo, Academia que se celebró en siete de Enero al feliz nacimiento del sereníssimo Príncipe Don Carlos..., Madrid, 1662, p. 6, de la primera Academia de las dos encuadernadas en el volumen cit. supra, n. 59).

${ }^{2} \mathrm{El}$ Dicc. Aut. recoge echar cédulas: "sortear sobre alguna cosa, como la noche de año nuevo, que se sortean santos, damas y galanes, escribiéndose los nombres en unas cedulitas pequeñas, las cuales se doblan, y después de revueltas se van sacando, y primero la del galán, después la de la dama, y el santo que les toca tener especial devoción aquel año. Lo mismo se ejecuta en los lugares cuando se sortea quién tiene que ir de soldado, y en las rifas para saber a quién ha de tocar la alhaja”. Además tenemos el otro sentido más ajustado a nuestro intento: cedulillas, "se llama así a los papeles que se llevan las Academias con diferentes asuntos" (Dicc. Aut.).

63 "Y en este punto se acabaron las cedulillas, pues desde que tomé la pluma, aseguro que no fue para escribirlas sino para volarlas" (Justa literaria y certamen poético en la canonización de S. Juan de Dios, p. 10). J. Puyol anota el episodio de los estudiantes de la Vigornia y dice que entre "las varias clases de cédulas que citan los Diccionarios, no aparece la cédula de disfraz, que era frecuente, por lo visto, en esta clase de diversiones. En el texto podemos ver que tales cédulas consistían en una especie de papeletas en las que se escribían pareados u otras clases de versos, y las cuales se repartían o se arrojaban desde el carro para que las recogiesen los espectadores" (F. LÓPEZ DE ÚBEDA, La pícara Justina, Madrid, 1912, t. 3, p. 139). 
naval de 1675, en la que su secretario, Francisco Bueno, describe una mojiganga en la que desfilan una fregona vestida de estudiante, un doctor en figura de centauro, un poeta disfrazado de botarga, un esporterillo en forma de gigante...

Corrió la voz de mi secretaría por las calles de la corte, y como son carnestolendas, los que la veían correr juzgaron que era perro con maza, y no se engañaron, porque no hay maza ni perro como haber de hablar en equívocos que llevan a la cola unas cedulillas. Corrió, pues, hasta que, viniendo yo por esta calle de las Hileras, encontré una mojiganga, muy del uso del tiempo, y como supiesen todos que en esta calle se celebraba una academia y que yo era su secretario, me pidieron que, en su nombre, la suplicase les diese unos motes que explicaran los enigmas de sus disfraces ${ }^{64}$.

Y algo también muy del tiempo: la constante alusión a los poetas remendones y a las escasez de invención ("polilla de otros poetas"), aunque en un contexto de fiesta y algarabía en el que queda claro lo habitual de remendar coplas. Un ejemplo: alguien se querella en una cédula porque ha sido víctima de un hurto, de un robo de letrillas, entremeses y bailes de China, y se queja porque entre lo robado se encontraban esdrújulos previstos precisamente para el remiendo:

Además muchísimos esdrújulos viejos que tenía en un arca, que servían para remendar otros, y los estimaba como poesía quebrada. Entre ellos iba una mojiganga o máscara del zodiaco y la zona tórrida en que había de salir Pitágoras guiando una danza de murciélagos, y después muchos ánsares, cada uno con su cálamo trémulo, cantando jácaras ${ }^{65}$.

La estructura de la cédula es conocida por repetida: retrato del personaje mediante un cúmulo de equívocos y otros recursos jocosos conocidos como la comparación divertida o el apodo. Es sabido que el equívoco es empleado con mejor o peor fortuna por infinidad de autores barrocos, pero estimo que es en vejámenes y cédulas donde se utiliza obsesivamente, con un empeño desesperado por provocar la carcajada mediante estos juegos verbales conocidísimos por el auditorio: "Empecemos en gracia de Dios con

64 Academia que se celebró por Carnestolendas..., pp. 3-4.

65 F. de la Torre Farfán, Templo panegírico, Juan Gómez de Blas, Sevilla, 1663, f. 59 r-v. 
unas que llaman cedulillas, por mi desgracia, las cuales paran en jugar las voces castellanas y, en habiéndolas perdido, tomar tantos (o la paranomasia que les corresponde) y proseguir el juego"66.

\section{CONCEPTISMO, DICTERIO Y FRASE HECHA}

En el seiscientos español hay un claro interés por domeñar y recrear los recursos del lenguaje figurado. Pienso que acierta Lia Schwartz cuando manifiesta duda acerca de la intencionalidad de los textos satíricos de Quevedo: "hasta tal punto el juego verbal se impone como la dimensión más importante del discurso" 67 . La sátira es un fenómeno intratextual ${ }^{68}$, cuyo referente puede ir de más general a más particular, y sobre el que se ejerce una actitud de reprehensión. Pero el humor no se reduce exclusivamente al ámbito de la sátira; hay otro, y muy abundante, que únicamente se queda en el orgullo y satisfacción del discurso proferido. Eugenio Asensio recoge una reflexión del poeta Auden respecto a la complacencia provocada por el lenguaje de la contienda de injurias, es decir, a una mayor atención a su desarrollo, a su destreza e invención que a la presencia real del contrincante. Reflexión que le lleva a matizar, a propósito del teatro de Quiñones de Benavente, que "las contiendas verbales no responden a movimientos de pasión, sino a exuberancia retórica, que en lugar de culminar en violencia física, se agota en violencia de lenguaje, en cascadas de imágenes e insultos" 69 .

Si partimos de esta premisa, de que existe un humor conceptista muy pagado de sí, habría que ver distante de toda intención docente a aquella literatura que censuraba e intentaba desterrar los dichos, los refranes, los modismos y las frases hechas. Quevedo, en su Cuento de cuentos, en su Pregmática de 1600 o en cien mil sitios más, criticó la costumbre de aducir en la conversación clichés lingüísticos. No obstante, en él no se produce un despiste de conciencia cuando utiliza en obras de menor fuste lo que tanto critica en otras de tono más elevado. Francisco Ynduráin ha dejado el terreno bien preparado: en estas obras el "artificio de compo-

66 Justa literaria y certamen poético..., p. 10.

${ }^{67}$ Lia Schwartz Lerner, Metáfora y sátira en la obra de Quevedo, Taurus, Madrid, 1986, p. 22.

68 Véase el ya clásico trabajo de Linda Hutcheon, "Ironie, satire, parodie. (Une approche pragmatique de l'ironie)”, Poétique, 1981, núm. 46, 140-155.

69 Eugenio Asensio, Itinerario del entremés, Gredos, Madrid, 1971, p. 146. 
ner un texto a puros refranes o modismos [no] tiene otra finalidad que sobrepase el dudoso gusto de superar el pie forzado propuesto"70. En otro momento, el profesor Ynduráin recoge las palabras de Merimée y de Seijas: "Quevedo no relegó al olvido los bordones y los modos de decir, antes bien les dio prestigio"; "la mayor autoridad que se puede aportar contra Quevedo es el mismo Quevedo"71.

Es muy común que en este tipo de literatura que refleja el abuso del acervo paremiológico se perciba una determinada actitud de reforma, actitud ésta de la que personalmente prefiero dudar al menos como cautela. Calderón o Rojas Zorrilla ${ }^{72}$ no tienen esas miras reformistas. Es el mismo caso de Gabriel Lasso de la Vega cuando escribe el romance "En estas Cortes se pide"73 o el de Pedro Espinosa y su novela "peregrina" El perro y la calentura ${ }^{74}$. Un hombre acostumbrado a vejámenes y academias fue Vélez de Guevara, como igualmente lo fue a trastocar refranes y modismos: "Las formas del conceptismo de Vélez en El diablo cojuelo son a base de modificar las frases hechas o los refranes", que decía Valbuena Prat $^{75}$. Se podrían aducir muchos ejemplos. Dos concisas líneas de Ynduráin nos sirven aquí de apoyo: en esta aparente cruzada contra las entidades idiomáticas sobresale un conflicto, el que se produce entre "unidades dadas, frente a una voluntad de estilo; lo colectivo y mostrenco, frente a lo individual; repetición, frente a invención" 76 . Dualidad ésta que puede verse igualmente en los vejámenes. Un cortesano, de esos "que han visto el teatro de los dioses y han leído la Historia del Cid y de los Pares, amolado de noticias y acicalado de ingenio", le aconsejaba al vejamista Marcos de Lanuza Mendoza que no se cansara "en ir a buscar el caballo de las musas, que no había necesidad de coplas a vista de las que habían salido estos días, que todo sería repetir, aun más que inventar"77. Algo similar sucede con el corpus de dichos, refranes y

70 FrANCISCO YNDURÁIN, "Refranes y «frases hechas» en la estimativa literaria del siglo Xviı", $A F A, 7$ (1955), p. 109.

${ }^{71}$ Ibid., pp. 110-111.

72 Ibid., pp. 119-122.

73 Gabriel Lasso de la Vega, Manojuelo de Romances, Saeta, Madrid, 1942, pp. 68-70.

${ }^{74}$ Pedro Espinosa, Obra en prosa, ed. de F. López Estrada, Diputación Provincial, Málaga, 1991, pp. 159-228.

75 La novela picaresca española, Aguilar, Madrid, 1986, t. 2, p. 694.

${ }^{76}$ F. YNduráin, "Refranes y frases hechas...”, p. 104.

77 Academia a que dio asumpto la religiosa y católica acción que el Rey nuestro señor ejecutó el día 20 de enero de... 1685. Celebróse el día 3 de febrero en casa de don Pedro de 
chistes derivados de la Floresta española de Melchor de Santa Cruz. Góngora, por ejemplo, se mofa de aquellos que a la mínima incorporan a su decir algo de la Floresta, pero él mismo cae en la falta que recrimina al reproducir en sus letrillas juegos de palabras provenientes de la obra de Santa $\mathrm{Cruz}^{78}$.

Tras Chevalier parece más que evidente que Quevedo culmina y trasciende ese carácter inmutable de la lengua ${ }^{79}$ : utiliza viejos materiales, españoles, muy de nuestro genio, y es consciente de ello como también lo es de su valía para inundar de novedad lo que el uso convirtió en fósil idiomático. Pero en esto veo más genio que gana de enmendar vicios de sus contemporáneos. Pienso que se da muy claramente en Quevedo ese intento de ser agudo y nuevo con una herencia vacía de contenido, pero que se veía como orgullosa distinción del carácter nacional. Si no se tiene en cuenta este nuevo uso del viejo acervo, ¿cómo entender entonces que las frases hechas sean uno de los recursos más utilizados a la hora de sacar al aire la brillantez y la agudeza verbal? Todo puede servir. Y, desde luego, hay una corriente temprana y muy definida en contra del refrán, pero es lo mismo, éste también puede valer, al igual que un apodo lexicalizado o una metáfora archiconoci$\mathrm{da}^{80}$. Es sabido que la agudeza se estimó como bien nacional, distintivo del abolengo español ${ }^{81}$, ¿qué mejor, pues, que ser agudo alterando de manera sorprendente lo que todo el mundo espera encontrar? ¿No podemos ver en el grave Gracián orgullo de autor y manifestación de agudeza cuando en la "Crisi" sexta de la terce-

Arce..., Sebastián de Armendáriz, Madrid, 1685, f. 35v. (He manejado el ejemplar existente en la Houghton Library, Harvard University, 89-535.)

78 Maxime Chevalier, "Unas reflexiones sobre el equívoco", Philologica Hispaniensia in honorem Manuel Alvar, Gredos, Madrid, 1986, t. 3, pp. 101-112, en concreto, p. 104.

${ }^{79}$ Maxime Chevalier, Quevedo y su tiempo: la agudeza verbal, Crítica, Barcelona, 1992.

${ }^{80}$ L. SchWARTZ a propósito de Quevedo: "Ahora bien, la lexicalización de la metáfora no implica que la relación establecida por la predicación deje de ser percibida. En otras palabras, para el receptor, la imagen actualizada en el momento icónico puede seguir funcionando a pesar de que la figura esté ya cristalizada en el uso lingüístico. Si la metáfora, por otra parte, sufre una leve modificación al ser integrada a un contexto literario más amplio, queda deslexicalizada y adquiere con ello más relieve” (op. cit., p. 45).

81 Cf., por ejemplo, Cristóbal de Villalón, "de aquí en adelante tengáis a los castellanos en más porque ellos mejor que otra alguna nación vsan deste género de agudeça” (El Scholástico, ed. de Richard J. A. Kerr, C.S.I.C., Madrid, 1967, p. 172). 
ra parte de El Criticón censura los refranes y los dichos de la lengua? Nótese que su crítica consiste en dar la vuelta a éstos y demostrar la incongruencia de su enunciado. ¿No admiraría al público que alguien le hiciera evidente el sinsentido de uno de sus más habituales modos de expresión? Búsqueda de admiración era también lo que llevaba a Alonso de Ledesma a sus famosos trastrueques de modismos, y a un deseo de revitalizar momentáneamente la fosilizada significación del giro y de la frase hecha. Lo resume muy acertamente Blanca Periñán:

Además de servir como autoridades vulgares aplicables metafóricamente, las frases pueden ser transformadas, con un proceso de resemantización que, sólo actuando sobre algo bien presente en la conciencia del oyente en su forma corriente, permite la alteración generadora, por sorpresa, de una nueva significación. Será una llamada al lector para que participe, remitiendo a algo notorio, ya sea un giro o un refrán o un estribillo popular y hasta un texto entero ${ }^{82}$.

Los versos de cabo roto con que Urganda la desconocida preludia el Quijote podrían, perfectamente, caer hacia este mismo sentido de querer dejar constancia del anquilosamiento idiomático que se sufría en ciertos sectores. Tanto si reflejan una sátira antilopesca como si tras ellos se esconde una no muy amistosa alusión a Francisco López de Úbeda ${ }^{83}$, el Quijote comienza con un ensartado de bordoncillos y refranes al uso. Es indiscutible que en los poemas burlescos con que se inicia el libro hay un deliberado afán de parodiar el convencionalismo, a veces abusivo, de las laudatorias preliminares ${ }^{84}$. De igual manera, no puede verse alejado de intención burlesca el arranque lingüístico elegido para la parodia quijotesca, es decir, con aquellos refranes y proverbios que los contemporáneos de Cervantes repetían una y mil veces. Mucho se ha conjeturado acerca de los elogios iniciales del Quijote, y de los epitafios suscritos por los académicos de la Argamasilla. Como ha puesto de relieve Márquez Villanueva, tanto unos como otros responden "a los dos polos temáticos de elogio y vejamen, con que se

82 Blanca Periñán, "Ciencia de la poesía y conceptismo. Técnicas de la sorpresa en Alonso de Ledesma”, Miscellanea di Studi Ispanici, 28 (1974), 97-156, cita en p. 145 .

83 Tesis esta última sostenida por Bataillon en Pícaros y picaresca: "La pícara Justina", Taurus, Madrid, 1969.

${ }^{84}$ F. MÁrquez Villanueva, "El mundo literario de los académicos de la Argamasilla”, LT, 1987, núm. 1, 9-43. 
abrían y clausuraban los actos académicos" 85 . Los nombres de los académicos, la referencia previa a Zaragoza y sus justas, los personajes elegidos para el ditirambo inicial, todo tiene una muy clara resonancia de academia. Como parte de esta atmósfera de burla y uso académico, Cervantes incluyó el estancamiento idiomático que en sus días caracterizaba, curiosamente, no sólo a personas de poca competencia lingüística, sino también a algo que se presentaba como distintivo del donaire nacional: el equívoco.

Notó Chevalier que en la España de 1600 viven muchos juegos verbales canonizados por el uso. Comprueba esta afirmación mediante un cotejo de los juegos empleados por dos autores que posiblemente desconocieran sus respectivas obras: Quevedo y Baltasar de Alcázar ${ }^{86}$. La coincidencia entre ambos refleja cómo se convierten en tradición muchas chanzas de la agudeza española. Esto puede verse claramente en los vejámenes, sobre todo en los más tardíos. La necesidad de que los asistentes a ellos identificasen y resolvieran con rapidez los juegos eliminaría de cuajo otra posibilidad de agudeza verbal no acuñada. Sin embargo, en muchos de ellos encontramos un enmarañadísimo enhebrado de equívocos, una auténtica orgía del ingenio conocido, reinsertado, trastocado. No sé si entonces costaría descifrar su significado, seguramente no, dadas las similitudes de muchos chistes; sí, desde luego, a un lector actual, que se vería incapaz de entender, a no ser que fuera un experto en el léxico de la burla, la práctica totalidad del texto si éste no anduviera acompañado de un gran aparato de notas. Pero la comprensión del texto no es, en última instancia, la única barrera.

La finalidad última de gallos y vejámenes es hacer gracias y juegos a costa del graduando, de los miembros de la academia o de los participantes en un certamen poético: apodar, mermar soberbia con los filos lacerantes de la agudeza; si bien se perciben cambios con el paso del tiempo. En muchos vejámenes, sobre todo en los más tardíos, en los de la segunda mitad del siglo XVII, se da algo que es producto de la desmesura a la que se había llegado: el frenético uso del equívoco, una auténtica red conceptista de disemias, calambures y disociaciones, y sin apenas engarce que suavizara los saltos de un juego de palabras a otro. A lo sumo que el vejado sirviera de marca o señal para que los asistentes notasen los cambios de registro. Aquí estriba su dificultad: el desconocimien-

85 Ibid., p. 24. De esta misma opinión es K. Brown, art. cit., p. 237.

86 Baltasar de Alcázar muere en 1600 sin haber impreso sus versos. 
to de las características que definen al personaje, su físico, su comportamiento académico, su vida particular y un sinfín de cosas que claramente determinaban la elección de los juegos de palabras. De nuevo Francisco Barbán de Castro, censor del vejamen de 1742 citado supra, nos ofrece una más que sugerente información:

Mas con una falta inevitable habrá de salir esta obra si se diere a la imprenta, pues aunque saldrá estampada la gracia y agudeza de los chistes y dichos, no podrán darnos todas las imprentas la que tienen y vimos los que tuvimos el gusto y honra de estar en el teatro, en las proporcionadas acciones y movimientos del autor, que son palabras mudas más vivas y expresivas a veces que las mismas voces. Con solo ellas se explicaban los Seros (pueblos de la otra parte del Indo), y hablaban entre sí mil chanzonetas graciosas y motes agudos. Y más solía Homero explicarse con la aguda energía de sus manos cuando hablaba, que con las voces de que se valía para expresar sus nobles pensamientos, tanto que Cicerón, émulo suyo, llamaba a sus acciones agudeza de dedos. Y siempre que oraba iban más a verlo que a oírlo (cf. supra, n. 10).

Retomemos tras esta digresión el asunto del equívoco. Todo tiene en el vejamen el mismo fin: elementos teatrales, chistes, cuentos, anécdotas mínimas como la de la involuntariedad del vejamista, en definitiva, aquello que configura este humillante y tradicional entretenimiento está casi en exclusividad al servicio del viejísimo equívoco español. Apodar, hacer motes, dar vaya, remoquete o matraca, eso es todo. Pero insisto: la afición por la agudeza se acentúa y no parece, como se ha dicho, que pierda vigencia según avanza el siglo, al menos en ciertos sectores poco exigentes con la creación. Estos vejámenes son una clara prueba: el conceptismo exagerado, popular, difícil por exclusivo. Un auténtico asedio a la lengua. Veamos algún ejemplo. En el Vejamen Granada 1679 la palabra "caballo" funciona como eje isotópico de un alarde polisémico:

Animal perfecto dijo el filósofo que era el hombre, y sin duda lo dijo por este animal, porque si no tiene estrella en la frente tiene en la cabeza una buena estrella, así tuviera rayos en ella. Él bebe con blanco, él tiene muy buenos cascos, él lleva muy bien cualquiera cosa de sus amigos cuando le dan carga, pues, ¿qué hay que pedirle a este animal? ¿Qué importa que sea cuatralbo? ¿No fuera peor que fuera zaíno? ¿Qué, un poco de rijo que tiene? Eso se le puede quitar a palos, como con la mano, que en fin es de esperanzas, y le vendrá un 
verde con dos azules de los cielos. Y para estas yerbas se ha de poner gordo como un caballo, pues sólo gasta en su caja cebadilla limpia de polvo y paja, con algunos granos de almizcle ${ }^{87}$.

"Estrella", “cascos", "blanco", "carga", "cuatralbo", "zaíno", "rijo", "verde", "cebadilla", "paja" son palabras que pertenecen al campo semántico de "caballería”, pero también pueden ser aplicadas a una persona. Y ahí no acaba la cosa: aun toca con su última esfera semántica al siguiente juego de ingenio, como si la palabra, caída en el agua, esparciera pequeñas olas de significación. El vejamista empieza a "trabajarse" a otro aspirante (Alonso Rozado), colegial de Santa Catalina, y se da a sí mismo un grito de ánimo para emprender la tarea: "por la mayor fortuna del mundo, y ande la rueda" 88 . Pues bien, la frase entera, proveniente de un juego infantil, es "ande la rueda y coz con ella", la última "coz" de un incansable conceptismo del que cuesta desentrañar sus límites significativos. Porque la palabra "rueda" también recoge la alusión de que el vejado es de Santa Catalina, y la "rueda de Santa Catalina" bien puede ser la que hace mover el volante de los relojes o bien aquella "que los saludadores se hacen estampar en alguna parte del cuerpo" (Dicc. Aut.).

El vejamista del Vejamen Granada 1687 está "estreñido", es decir, parado, sin ideas para hacer el vejamen, y alguien le ofrece una "ayuda" de equívocos que le hicieran "echar las tripas". Recuérdese que una de las acepciones de "ayuda" era la de "clister". Este juego es sencillísimo a tenor del enmarañamiento al que se podía llegar. Se dice del personaje que se ofrece a colaboración que vive en la calle de la "marañas". Bien, pues esta palabra es el núcleo axial sobre el que va a girar el inmediato equívoco:

¿Hay tal enredo — quedé diciendo-que siendo yo una madeja sin cuenda me haiga el diablo dado esta cruz? Mas pues remedio no tiene, tiremos la hebra, que Dios sacará al cabo, y puede ser que aspe a los graduandos, y de todos haga un ovillo ${ }^{89}$.

Hay juegos, claro, celebérrimos y de vieja escuela: "yerro" ("espuela' y 'error'); "irse" ('marchar' y 'ventosear'); "cerote” ('cera

87 Vejamen que dio el doctor don Andrés Muñoz Chamizo, médico y catedrático de método en la imperial Universidad de Granada el 10 de Marzo de 1679, volumen de varios vejámenes cit. supra, n. 10, f. 9v.

88 Ibid., f. 10r.

89 Ibid., p. 7 (Vejamen que se celebró en la imperial Universidad de Granada...). 
de zapatero' y 'excremento'); el tan socorrido de "dar" y "tomar", etc. Pero hay otros imprevisibles y de gran complejidad. También del Vejamen Granada 1679 es la siguiente redondilla:

\author{
Menos su nariz echaba, \\ Y un día que la buscó \\ En un muladar la halló \\ Que allí oliendo mal es-taba ${ }^{90}$.
}

A partir de aquí se produce un cambio de personaje y de registro, cambio indicado por el calambur construido mediante el pretérito imperfecto del verbo "estar" y la "taba". La "taba": "tomar la taba... que alguno empieza a hablar con priesa, después que otro lo deja" (Dicc. Aut.). "Tomar la taba en hablar o algo. Es de un jueguecillo que llaman taba" (Correas). Juego que, a pesar de ser conocido ${ }^{91}$, debía de dar sus problemas a los que lo oyeran. Quizá esto explique que los vejámenes se llevasen a imprenta, por la tal cantidad de equívocos que in situ no llegarían a entenderse. Porque su gracia estaba en desentrañar el velo conceptista, descubrir a quién se aludía, cómo y por qué, y en la complacencia de llegar a la definitiva resolución del conflicto: dar con el dicterio.

Relacionar el dicterio con la "pulla", "el mote", "el apodo", "la agudeza", es trabajo ya realizado por Monique Joly. En su célebre tesis doctoral ${ }^{92}$ sobre la lengua de la burla, la profesora Joly comprobó cómo los textos nos llevan irremisiblemente ante el debate de la mesura y el exceso en el manejo de la palabra graciosa ${ }^{93}$. Y no creo que se trate tanto de un problema de límites como de recepción. Dónde acaba el ingenio y dónde empieza la injuria no es cuestión que se vea tipificada por criterios universales de moralidad o de buen gusto. Temo que, una vez más, habría que entrar en contextos y estimativas, algo de lo que conocemos bien poco.

${ }^{90}$ Ibid., f. 9v (Vejamen que dio el doctor don Andrés Muñoz Chamizo...).

${ }^{91}$ Véase para este juego Rodrigo Caro, Días geniales o lúdicos, ed. de J. P. Etienvre, Clásicos Castellanos, Madrid, 1978, t. 1, pp. 174-190.

${ }^{92}$ Monique Joly, La bourle et son interprétation. Recherches sur le passage de la facétie au roman (Espagne, xvié-xviie siècles), Université de Lille III, Lille, 1986. Véanse también, entre otros, J. P. Wickersham CraWFord, “Echarse pullas': a popular form of tenzone", RR, 6 (1915), pp. 150 ss.; L. SpITzer, "Notas etimológicas", RFE, 10 (1923), 373-375; O. Deutschmann, "Formules de melédiction en espagnol et en portugais", BdFS, 10 (1949), 215-272; L. SCHWARTZ, "El juego de palabras en la prosa satírica de Quevedo”, ALM, 11 (1973), pp. 149-175, y M. Chevalier, art. cit.

${ }^{93}$ M. Joly, op. cit., p. 231. 
Puede que el origen del mote esté en los pasatiempos palaciegos, en el intercambio de pequeñas estrofas "facetiosas" 94 . Desde luego, sufrir burlas era exigencia de buen cortesano:

\author{
Que la gala, y la blancura, \\ donayre, y gusto excelente, \\ es profesión más decente \\ de la bizarra hermosura. \\ La burla, el chiste, el concepto, \\ y la plática también, \\ de quien es galán, y quien \\ fino, atinado, y discreto ${ }^{95}$.
}

Las burlas sufrirlas, pero no usarlas. Aquello es especie de galantería, esto de empeño. El que en la fiesta se desazona, mucho tiene de bestia, y muestra más. Es gustosa la burla, saber sufrir es argumento de capacidad. Da pie el que se pica a que le repiquen ${ }^{96}$.

Este ser elegante en la mordacidad y en la aceptación de saberse víctima de la misma, ¿no podría relacionarse con la recepción que el discurso del bufón provocaba en los salones de la más encopetada alcurnia? Se sabe que la maestría en encontrar comparaciones injuriosas, o, lo que es lo mismo, el arte del apodo ${ }^{97}$, era actividad asociada estrechamente con el personaje del bufón ${ }^{98}$;

94 Ibid., p. 234.

95 A. Hurtado de Mendoza, apud Gareth A. Davies, A poet at court: Antonio Hurtado de Mendoza (1586-1644), The Dolphin Book, Oxford, 1971, p. 104.

${ }^{96}$ Gracián, Oráculo manual y arte de prudencia, en Obras completas, ed. de Arturo del Hoyo, Aguilar, Madrid, 1967, p. 216.

97 "Hasta los amigos, en llegando a reñir, parecen verduleras que se echan las faltas en la cara, llamándose apodos" (Vejamen que se celebró por Carnestolendas..., p. 98).

98 Ibid., p. 98. Joly, en otro trabajo, definía el "apodar" como "usar de una comparación festiva a propósito de una persona" ("El truhán y sus apodos", NRFH, 34, 1985-86, 723-740, cita en pp. 726-727). Para la literatura del loco véanse M. BigeARd, La folie et les fous littéraires en Espagne, 1500-1650, Paris, 1972; F. MÁrQueZ Villanueva, "La littérature du fou en Espagne", en L'Humanisme dans les lettres espagnoles, dir. A. Redondo, Paris, 1979, pp. 233-250, versión española en Sin Nombre, 10 (1980), 7-25; "Sebastián de Horozco y la literatura bufonesca", en Prosa y pensamiento en la época del Emperador, Academia Renacentista, 5 (1988), 131-163 (véase la bibliografía aquí incluida en notas 1 a 4); Visages de la folie (1500-1650), eds. A. Redondo y A. Rochon, Paris, 1981 y el volumen monográfico dirigido por F. MÁrQuez Villanueva, "Literatura bufonesca o del loco" ( NRFH, 34, 1985-86). Para la figura histórica del bufón, véanse el célebre trabajo de Moreno Villa, Locos, enanos, negros y niños palaciegos. Gentes de placer que tuvieron los Austrias en la corte es- 
y éste gozó, con venia real, de una clara permisión a la hora del "decir" y del "tocar" a los distinguidos invitados. ¿Se podría, pues, hablar de una especie de escuela cortesana en la que, a base de agresiones bufonescas, adquiriese categoría de elegante distinción la burla vejatoria? Si así fuera, la tolerancia habría de extenderse a rincones menos selectos. Comienza de la siguiente manera el $V e^{-}$ jamen que dio el Doctor Salcedo al doctor don Alonso de Salazar en la Universidad de Granada el año de 1598: "Decía el emperador Segismundo que decir motes agudos era nidal de discretos y sufrirlos con discreción era valor de sabios" 99 . Esto sólo quiere decir que también en vejámenes se aludía a esta obligación cortesana de saber soportar la carga de la burla. Sería muy útil, pues, no desatender la posible relación entre el ineluctable vejamen, la chocarrería que gastaban bufones y truhanes y el uso de corte de tener que apechar con agresiones verbales. Ya vimos que en los vejámenes se apelaba a una secular tradición. No pocas veces este recurrir a la costumbre se aplicaba de igual manera a la maledicencia en general, aislada del contexto que la vio surgir. Tenemos un buen ejemplo en Antonio Hurtado de Mendoza, poeta, por otra parte, habitual de academias y fiestas:
Un maldiciente profeso no puede hacer pesadumbre, hable gordo o muerda tieso, porque a todos de su exceso desagravia su costumbre ${ }^{100}$.

La tan traída costumbre. Y, como sucede con la mayoría de las convenciones, la antigüedad a la que se acude es indefinida en el tiempo. Esto es algo que vemos en el mismo Scholástico, cuando uno de los interlocutores reacciona con energía ante la censura que alguien hace de la práctica nacional del motejar:

Y si no me creeis leed qué persona fue Tulio en eloquençia y saber y quánto dello se preçió de tocar a todos los varones de estima de su tiempo con motes y donaires de mucha graçia: y si todos lo su-

pañola desde 1563 a 1700, México, 1939 y el de Fernando Bouza, Locos, enanos y hombres de placer en la corte de los Austrias, Ediciones Temas de Hoy, Madrid, 1991.

99 A. Egido, "Un vejamen de 1598...", pp. 175-204.

100 Antonio Hurtado de Mendoza, Obras poéticas, ed. de Rafael Benítez Claros, Real Academia Española, Madrid, 1947, t. 2, p. 232. 
frían sin se afrontar era por que vían que era cosa muy vsada y de gran loor ${ }^{101}$.

"Era cosa muy usada" ya en los lejanos tiempos del rey romano Hostilio Tulio o en la época del emperador alemán Segismundo, pero eso es todo, origen remoto y vaguedad. Por otro lado Martín de Azpilcueta, en su Manual de confesores y penitentes, al definir y elaborar una tipología del escarnio, también hace referencia al ambiente cortesano en el que el dicterio es moneda corriente, y en el que la muestra de corrimiento servía para incrementar aun más la virulencia del improperio:

Parece también mortal cuando se hace para, grave y notablemente, avergonzar, o correr, o confundir a otro, o cuando se sigue tan notable turbación, advirtiendo, o debiendo advertir, que se seguiría tal de su sobrada burla y escarnio... en que muchas veces caen los cortesanos, que sin duelo alguno tanto más burlan de uno cuanto más se corre de ello ${ }^{102}$.

Sabemos que el dicterio envuelto en burla no es privativo de cortesanos. El caso es que existe una burla, de procedencia bastante incierta, que se da no tanto como regocijo que como mero requisito del protocolo. Si dispusiéramos de vejámenes más antiguos tal vez nos dejarían vislumbrar aspectos de su naturaleza primigenia, ya que los del siglo XVII contienen evidentes interferencias con la resignación aconsejada por los discretos de la corte. Sospecho que nos llevaríamos una sorpresa si encontrásemos algún gallo de fines del xv o de los primeros años del Xvi. Quizá el secreto esté, al estimar al gallo teológico como el origen del vejamen ("Ceremonias burlescas...", pp. 144-148) en aquella literatura jocosa de las escuelas clericales o en esas ridículas ceremonias cenobíticas que Alan C. Soons nos recordaba ${ }^{103}$.

101 C. DE Villalón, op. cit., p. 172.

102 Martín de AzPilcueta, Manual de confesores y penitentes, que clara y brevemente contiene la universal y particular decisión de cuasi todas las dudas que en las confesiones suelen ocurrir..., Andrea de Portonariis, Salamanca, 1556, cap. 18, núm. 15, pp. 314-315. Una vez más, véase F. LAYNA, “Ceremonias burlescas...”, p. 153.

103 "Es verdad que se ha teorizado que hubo cierta ceremonia cenobítica denominada ridiculum celebrada entre los conventuales, y que la fabliella no hace más que traer vestigios de un origen eclesiástico" (Alan C. Soons, Haz y envés del cuento risible en el Siglo de Oro, Tamesis, London, 1976, p. 19). Véase el capítulo "Bromas y veras en la literatura medieval" de E. R. CuRTius, Literatura europea 
¿Dos, tres líneas distintas que confluyen en la misma dicacitas? No tengo respuesta. Pero sí me gustaría traer a colación unas palabras de Eugenio Asensio que no han sido, a mi modo de ver, suficientemente tenidas en cuenta. Se sorprende Asensio al comprobar que en el entremés Los alcaldes de Quiñones de Benavente, tras los intercambios de pullas y vituperios de los personajes, los músicos cantan alegres la gracia de la recién acabada refriega de motes y burlas, y se pregunta, con una más que apreciable prudencia: "¿Nos faltará el sentido deportivo de la injuria? ¿O estaremos desorbitando las cosas cuando encontramos hirientes, más que humorísticos, los epigramas y equívocos?"104. Desde luego la pregunta parece desestimada para ciertos contextos, como, por ejemplo, el de los vejámenes más tardíos, pero es muy válida y razonable para sopesar las causas que en su día dieron origen a esta práctica vejatoria. Es la de Asensio una sospecha que no suele ser formulada, y que puede funcionar como aviso o recordatorio de que los análisis sobre la génesis de la burla no pueden por menos de ser provisionales, sobre todo si se considera lo burlesco como algo no universal ni unitario, y muy determinado por el contexto en el que surge. En otro momento, Eugenio Asensio refiere algo que hay que tener presente a la hora de añadir comprensión al problema que nos atañe: "Dos factores alimentaron el caudal de chistes: la necesidad de esquivar los castigos que la ley imponía al que otro apedillase marrano judio, y la ingeniosidad de que se preciaba la corte, vivero de hombres de raça" ${ }^{105}$. Es de imaginar que en las atmósferas cortesanas muchos de estos chistes antijudaicos fueran la prueba de fuego para pasar por cristiano de rancio linaje, es decir, saber soportar la invectiva era señal de que la broma sólo quedaba en eso, en broma, y no en herida del orgullo religioso o cultural que delatara sospechosa condición. De ahí el disimulo del sentimiento, no fuera que alguien sacara a relucir aquello de "quien se pica ajos come".

Francisco Layna RanZ Harvard University

y Edad Media latina, trads. A. Alatorre y M. Frenk, F.C.E., México, 1955, t. 2, pp. 594-618; F. LóPEz EsTRAdA, "Manifestaciones festivas de la literatura medieval castellana”, en Formas carnavalescas en el arte y la literatura, ed. J. Huerta Calvo, Serbal, Barcelona, 1989, p. 76.

${ }^{104}$ Eugenio Asensio, Itinerario del entremés, p. 157.

105 Ibid., op. cit., p. 151. 